Article 176

Received: June 10, 2020

Accepted: September 14, 2020

\title{
DEFINITION OF PULSE SIGNAL PARAMETERS AND THE PROCESS OF MEASURMENT WITH EXPERIMENTAL VERIFICATION AND SIMULATION IN MATLAB
}

\author{
Filip Simjanoski, Dimitar Taškovski, Živko Kokolanski \\ Faculty of Electrical Engineering and Information Technologies, \\ "Ss. Cyril and Methodius" University in Skopje, \\ P.O. box 574, 1001 Skopje, N. Macedonia \\ filip.simja@gmail.com
}

\begin{abstract}
A b s t r a c t: In this paper, the parameters of pulse signals and algorithms for their calculation are presented following the latest standards and guidelines in the field. The focus of the paper is related to the evaluation of the signal parameters in laboratory conditions and the comparison between the experimental and simulation results. The paper proposes a methodology for determination of pulse parameters of a communication network model simulated in MATLAB and confirmed by a laboratory measurements. Since many parameters can be used to define pulse signals, this research highlights the most commonly used in the science and industry. On the other hand, some of the influencing factors have negligible effect on the measurements and therefore they will be mentioned but not evaluated in the paper.
\end{abstract}

Key words: pulse parameters; pulse metrology; pulse measurement; MATLAB

\section{ДЕФИНИРАЫЕ И МЕРЕЊЕ ПАРАМЕТРИ НА ИМПУЛСНИ СИГНАЛИ ПРЕКУ ЕКСПЕРИМЕНТАЛНА ВЕРИФИКАЦИЈА И СИМУЛАЦИЈА ВО МАТLАВ}

\begin{abstract}
А п с т р а к т; Во овој труд се претставени параметрите на импулсните сигнали и алгоритмите за нивна пресметка следејќ ги најновите стандарди и упатства од дадената област. Фокусот на трудот е поврзан со процената на параметрите на сигналот во лабораториски услови и споредбата помеѓу експерименталните резултати и симулациите. Во трудот се обработува методологија за определување на параметрите на импулсните сигнали согласно со моделот на комуникациска мрежа симулиран во MATLAB и потврден со лабораториски мерења. Имајќи предвид дека постојат повеќе параметри коишто можат да се искористат за дефинирање на импулсните сигнали, ова истражување ги истакнува само најчесто користените во науката и индустријата. Од друга страна, некои од факторите на влијание имаат незначителен ефект врз мерењата и затоа тие во трудот се споменати, но не се детално елаборирани.
\end{abstract}

Клучни зборови: параметри на импулсни сигнали; импулсна метрологија; мерење на импулсни сигнали; MATLAB;

\section{INTRODUCTION}

Pulse metrology is the science of the measurement related to pulses and their parameters [1]. It is the ability to measure pulse signals in a repeatable and reproducible manner with an adequate measurement uncertainty. Each measurement has its measurement uncertainty characterizing the dispersion of the quantitative estimations being attributed to the measurement [2]. Pulse measurements are widely used for many applications, but determining the measurement uncertainty and describing the sensitivity of each contributing factor can be challenging and only top tier national metrology institutions have developed standards and artifacts in this area. Pulse parameters differ when calculated by different manufacturers, and therefore terms related to transitions, pulses and waveforms, definitions and de- 
scriptions of techniques and procedures for measuring their parameters are important. The standards IEEE 181-2011 [3], and IEC 60469:2013 [4], provide such definitions and algorithms for calculation of pulse parameters. Having in mind the broad applicability of electrical pulse technology in the electronics industries (such as computer, telecommunications and test-instrumentation), the development of unambiguous definitions for pulse terms, and the presentation of methods and/or algorithms for their calculation is very important [5]. In addition, with the development of Field Programmable Gate Arrays (FPGA) and processor power of personal computers, real-time measurements and uncertainty analysis are possible ranging from slow to ultra-fast pulse metrology. The availability of such digitalized procedures helps laboratories and consumers to better compare the performance of different products and test the equipment with better precision. The technological improvements, especially by development of digital waveform recorders have facilitated the capture, sharing and processing of signal waveforms. Very often these waveform recorders have the ability to process the waveforms internally and directly calculate the pulse parameters. This process can be done automatically and without operator intervention.

This paper proposes a MATLAB model for a transmission line commonly used for communication in electricity meters. The simulation model was implemented, tested and compared to the experimental measurements in order to detect the difference and provide the possibilities for future research and improvement. Consequently, definitions and methods of computation for pulse parameters are given and compared with other related papers.

\section{SIGNAL DEFINITION AND INSTRUMENTATION}

In the domain of pulse generation and measurement one have to use a specialized instrumentation, e.g. function generators and oscilloscopes. The instruments used for the experimental measurements are as follows:

- Arbitrary function generator AFG3021. This instrument is capable of generation of arbitrary waveforms and pulse generation. It can be used for electronic tests and design, sensor simulation, functional tests, education and training [6].

- Digital oscilloscope TDS1002, with real-time acquisition up to its full bandwidth of $60 \mathrm{MHz}$ with advanced triggers to isolate signals of interest and other standard automatic measurements [7].

The instrumentation used in the experiments must be traceable to the top tier laboratories in the world like (NIST, NPL and PTB) [8]. Also other laboratories have developed a traceability chain between ultrafast electrical pulse waveforms and the SI [9]. This paper was focused on low frequency signals, which have commercial use in smart electricity meters, as defined in IEC 62053-31 [10]. The pulse parameters were set to match the realistic scenario of a smart meter output, whereas the circuit of the cables was designed in MATLAB Simulink to show the impact of the cable length. The signals used both in the simulation and the laboratory experiment are given in Table 1.

\section{Table 1}

Pulse parameters values of the signal

\begin{tabular}{lcc}
\hline \hline Parameter & Value & Unit \\
\hline Reference level at the first instant & 0 & $\mathrm{~V}$ \\
Amplitude & 5 & $\mathrm{~V}$ \\
Delay & 0 & $\mu \mathrm{s}$ \\
First transition duration & 100 & $\mu \mathrm{s}$ \\
Second transition duration & 100 & $\mu \mathrm{s}$ \\
Pulse duration & 35 & $\mathrm{~ms}$ \\
Waveform period & 90 & $\mathrm{~ms}$ \\
\hline \hline
\end{tabular}

For the simulation and the experimental measurements MATLAB and a specialized oscilloscope software were used to precisely determine the value of the parameters. The signal used to simulate an energy meter with constant power consumption was defined with a frequency of $11.11 \mathrm{~Hz}$. The signal generated in MATLAB Simulink is shown in Figure 1.

\section{DEFINITION OF PULSE SIGNAL PARAMETERS}

Each of the state occurrences in a signal waveform can be described, and can be used to define different signals. However, few of these parameters can be applied to each signal. Regarding the signal parameters given in Table I, the values of three parameters will be evaluated and compared in this paper. 


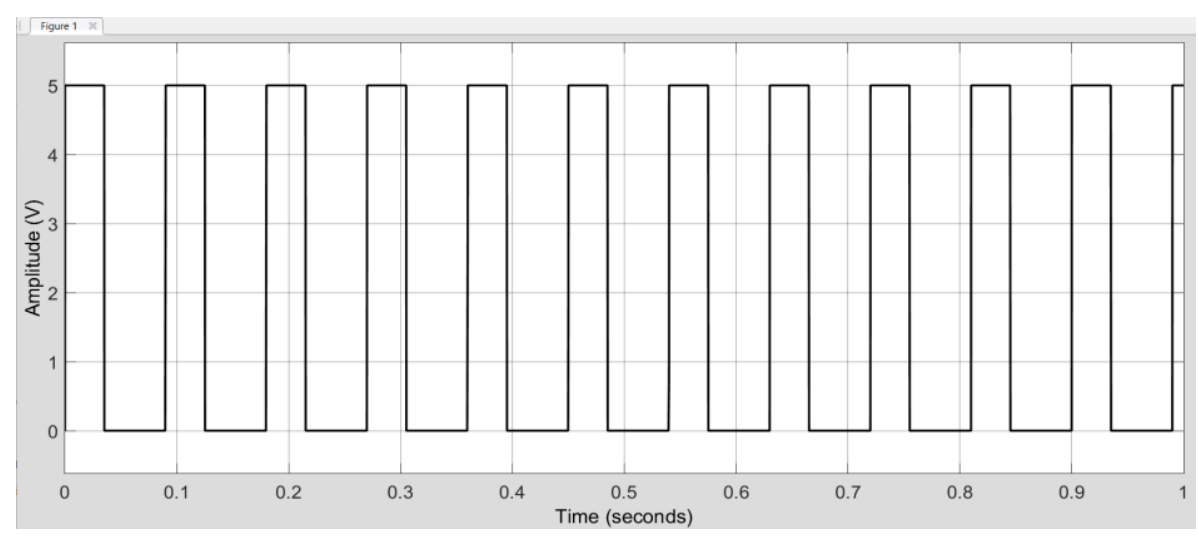

Fig. 1 Signal generated in MATLAB

According to [11] the following definitions have to be applied:

- Pulse amplitude is the difference between the specified level corresponding to the maximum peak (or minimum peak) of the positive (or negative) pulse-like waveform and the level of the state preceding the first transition of that waveform.

- Waveform amplitude is the difference between the levels of two different states of a waveform. Two different definitions for amplitude are given by this standard because they are both in common use. In all applications of this standard, the chosen definition shall be clearly identified. The two definitions are as follows:

- Signed waveform amplitude is the level of the state succeeding a transition minus the level of the state preceding the same transition.
- Unsigned waveform amplitude is the absolute value of the signed amplitude.

- Transition duration is the difference between the two reference level instants of the same transition. Unless otherwise specified, the two reference levels are the 10\% and $90 \%$ reference levels.(Figures 2 and 3 ).

If the upper and lower state boundaries of the two states are not the user-defined reference levels (for example, the $10 \%$ and $90 \%$ reference levels), then the duration of a transition is not equal to the transition duration [3].

- Overshoot is a waveform aberration within a post-transition aberration region or pre-transition aberration region that is greater than the upper state boundary. If more than one such waveform aberration exists, the one with the largest magnitude is the overshoot unless otherwise specified.

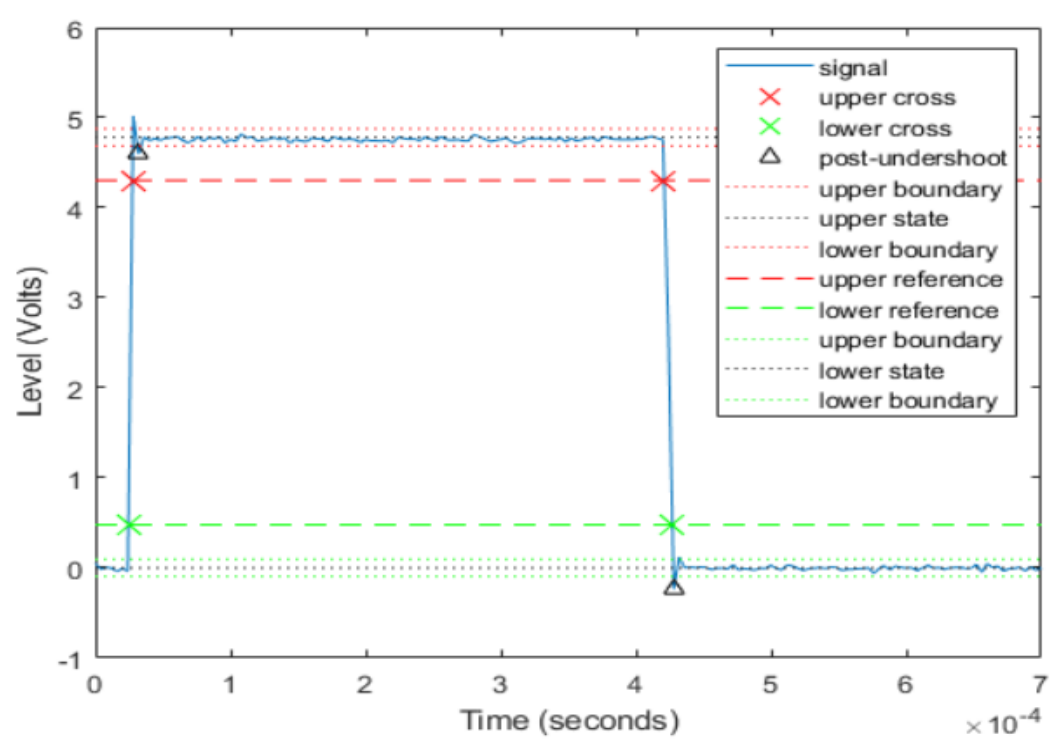

Fig. 2. Two-states pulse signal simulated in MATLAB 


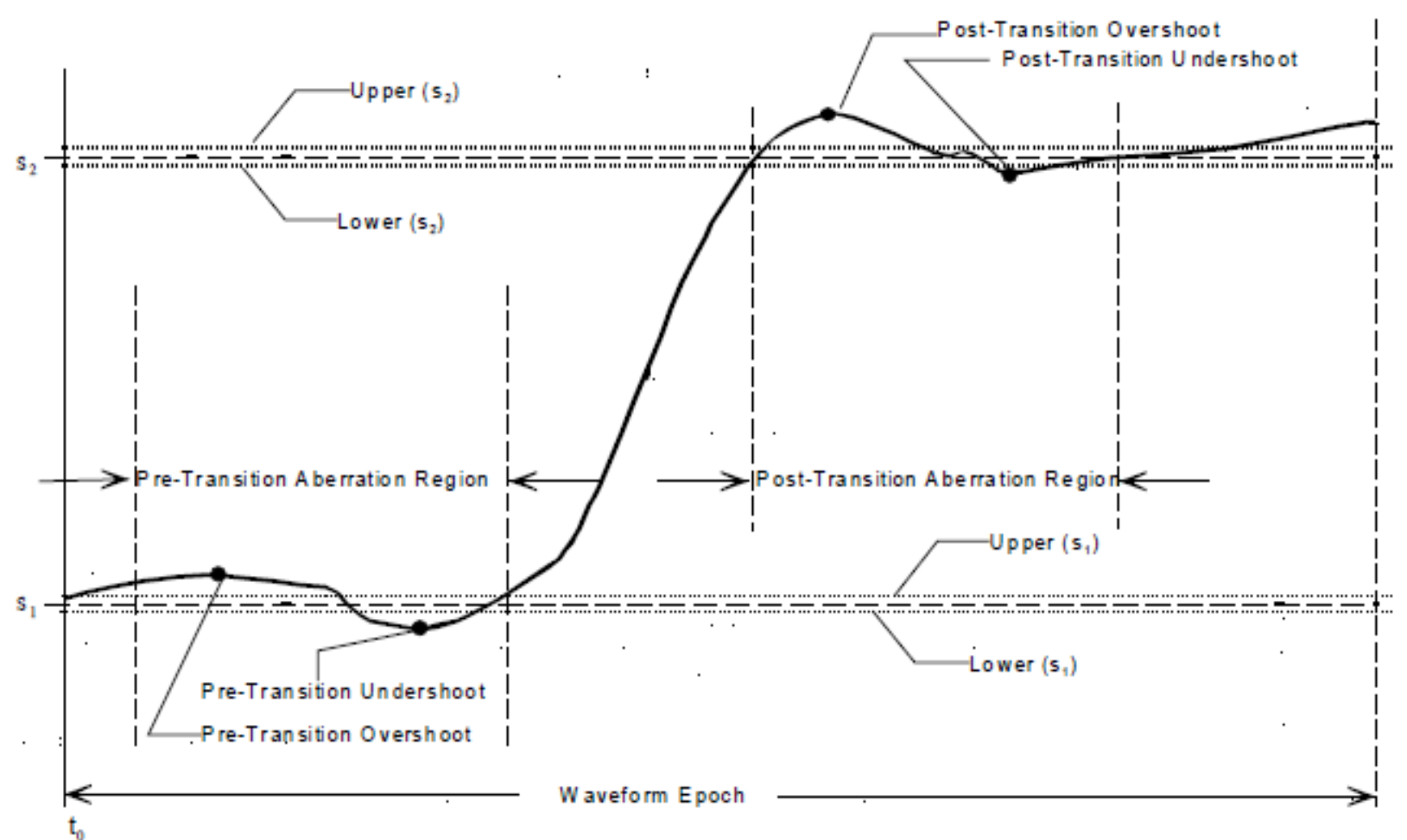

Fig. 3. Overshoot and undershoot in single positive transition

\section{SIMULATION OF THE SIGNAL IN MATLAB SIMULINK}

The signal path influences the measurement process, which is often quantitatively negligible on the signal itself and its parameters. The current-loop signal has the advantage of being robust against electromagnetic interference and voltage drop on the connecting cable and can detect physical connection failures, such as broken cables. The effects of electrical parameters on the conductors, primarily the parasitic components, and the insulation through which the signal is transmitted, certain additional joints or electromagnetic influences from surrounding conductors can disturb the signal [11].

In this section, the focus is on the influence of conductors and the different scenarios in which they distort the pulse signal. After the simulation results obtained with MATLAB Simulink, experimental measurements are performed with the same circuit. The aim is to show in practice weather they can have a significant impact, but also to prove in which circumstances they can be neglected and insignificant. This will serve to obtain certain signal distortions that will be defined as S0 type Class A pulses according to IEC 62053-31 [10].

Electrical transmission cables can be mathematically modeled depending on the frequency of the signal to be transmitted. Unlike high-frequency transmission signals, low-frequency electrical transmission cables (such as metering cables for monitoring the consumption of electric meters) can be modeled using a simple cable model. In this paper, a simple cable model from a manufacturer datasheets is used for a simulation. It has been confirmed that for short cable lengths, as commonly used in metering applications, the equivalent cable circuit will not cause a noticeable change in the number of pulses or their waveform. Then using the comercially available $\mathrm{R}, \mathrm{L}$, and $\mathrm{C}$ components, an RLC circuit is dimensioned so that it will disturb the signal and yield different parameters than the ones generated, described in chapter 3 . It is well known that a cable is represented by its electrical resistance, capacitance, and inductance that may have different electrical connections, mounted at separate points along the cable. Various models were analyzed during within the research prior this paper, and hence, it was decided to use the best-known RLC circuit model given in Figure 4.

Unlike resistors, the voltage across the capacitor changes with time. The dependence on which the voltage changes as a function of time is proportional to the charge current through it and inversely proportional to the magnitude of its capacitance [11]. 


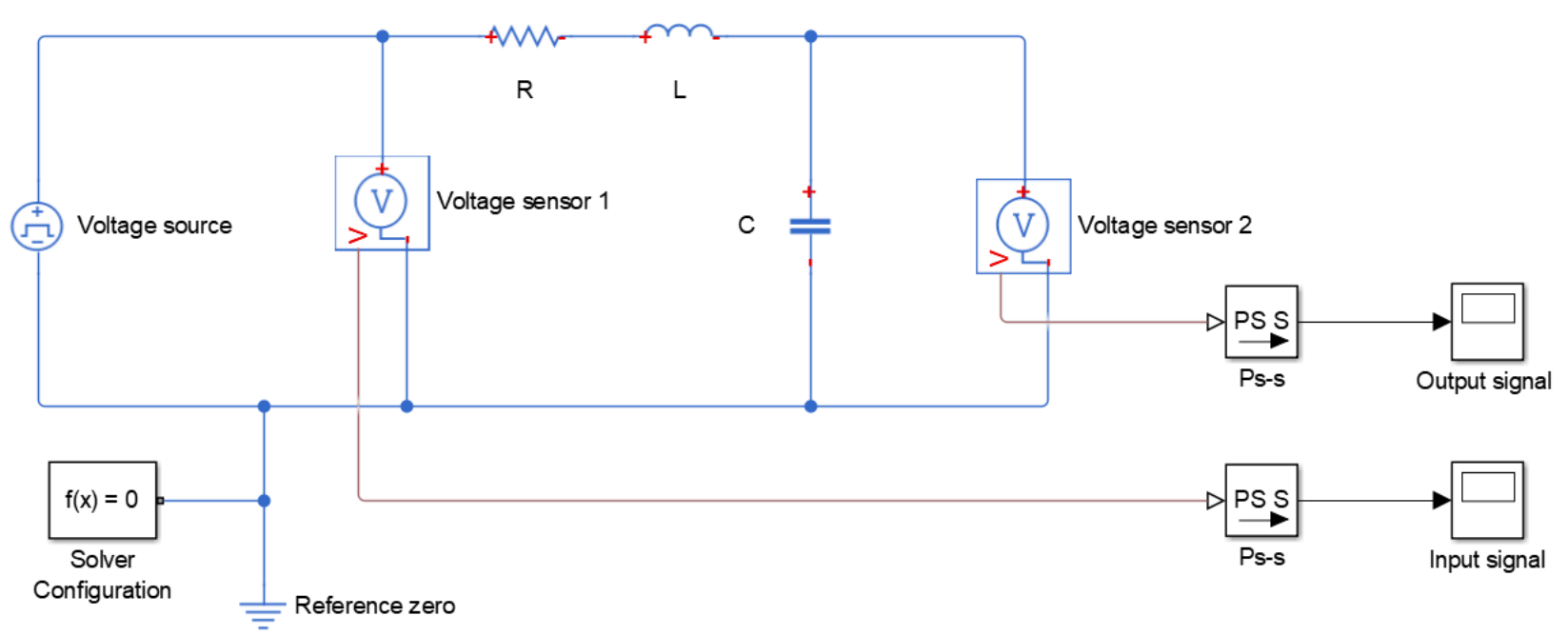

Fig. 4. MATLAB model of the communication interface

For the inductor, the charge current changes over time and is proportional to the voltage of the inductor and inversely proportional to the magnitude of the inductance [11], as shown in equations:

$$
\frac{d U_{C}(t)}{d t}=\frac{1}{C} \cdot i_{C}(t) \Leftrightarrow i_{C}(t)=C \cdot \frac{d U_{C}(t)}{d t}
$$

For the inductor, the charge current changes over time and is proportional to the voltage of the inductor and inversely proportional to the magnitude of the inductance [8], as shown in equations:

$$
\frac{d i_{L}(t)}{d t}=\frac{1}{L} \cdot V_{L}(t) \Leftrightarrow V_{L}(t)=L \cdot \frac{d i_{L}(t)}{d t}
$$

At the end there is a scope to measure the output voltage, and with the build in block Scope, the simulation after completion measured the amplitude, transition duration and the overshoot.

\section{EXPERIMENTAL MEASUREMENTS AND DISCUSSION}

In order to perform the measurement and experimentally determine the pulse parameters described in Chapter 3 and compare these values with the simulation in MATLAB, an experiment was performed to generate the signal and measure the output of the circuit given in Figure 4. All the blocks of the measurement process given in Chapter 4 were replaced with realistic instruments. The experiments were related to a power meter realistic pulse signal, without any distortions. Such a signal is referred to as a $\mathrm{S} 0$ - class A. This is the type of pulse signal that can be found in industrial applications when remotely reading or transmitting power consumption. The values of the $\mathrm{R}, \mathrm{L}$ and $\mathrm{C}$ components were selected the same as the ones used in the simulation. The oscilloscope was used to precisely determine the pulse signal parameters, where a multiple measurements were performed in order to calculate the type A measurement uncertainty. The purpose of this measurement is only to determine its value. The measurement result is only an approximation of the correct value and is thus completed only when accompanied by a value for the uncertainty of that estimate. In practice, the required specification or definition of the measured value is accompanied by an uncertainty interval. The measured value should be defined in terms of the required accuracy, so that for all practical purposes related to the measurement its value is unique [13].

According to the pulse parameters definition these equations are used by the software to determine the analyzed parameters [3]. The amplitude is defined as:

$$
A=\operatorname{level}(s 2)-\operatorname{level}(s 1),
$$

where $A$ is the amplitude of the waveform, $s_{1}$ and $s_{2}$ are the state levels of the signal.

Transition duration is expressed as:

$$
t_{90 \%-10 \%}=t_{90 \%}-t_{10 \%},
$$

where $t_{90 \%-10 \%}$ is the time as the difference between $90 \%$ and $10 \%$ reference level instants for the same reference levels.

Overshoot (aberration):

$$
O_{\text {pre }}(\%)=\frac{y_{\text {max }, p r e}-\operatorname{level}\left(s_{2}\right)}{|A|} 100 \%,
$$

where $O_{\text {pre }}$ is the overshoot value in the pre-transition aberration region, $y_{\text {max,pre }}$ is the maximum 
waveform value in the pre-transition aberration region, $A$ is the waveform amplitude, level(s2) is the state level for a positive-going transition.

The scope of this experiment was to prove the justification of some factors in the measurements, but also to point out the factors that must be included in the further uncertainty analysis. Some discrepancies were noted between the simulation and the actual measurements, which is to be expected given the metrological performances of the instruments as presented in Chapter 2. The values taken to generate a distorted signal were selected according to the mathematical model given in Chapter 4, so that the observed aberrations give the opportunity to characterize and compare the results. Figure 5 shows the laboratory instrumentation setup, where as Figure 6 shows the graph of the waveform obtained from the experiment which was performed for $R=1 \Omega, L=3 \mathrm{mH}, C=5.1 \mathrm{nF}$ and the circuit from the simulation shown in Figure 4.

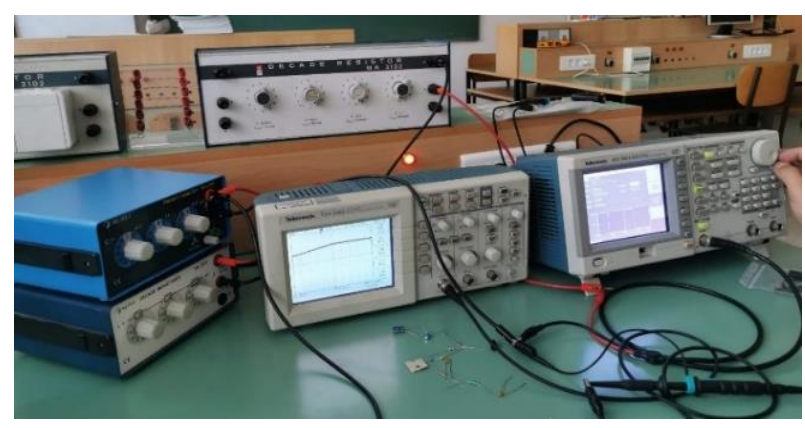

Fig. 5. Laboratory instrumentation setup

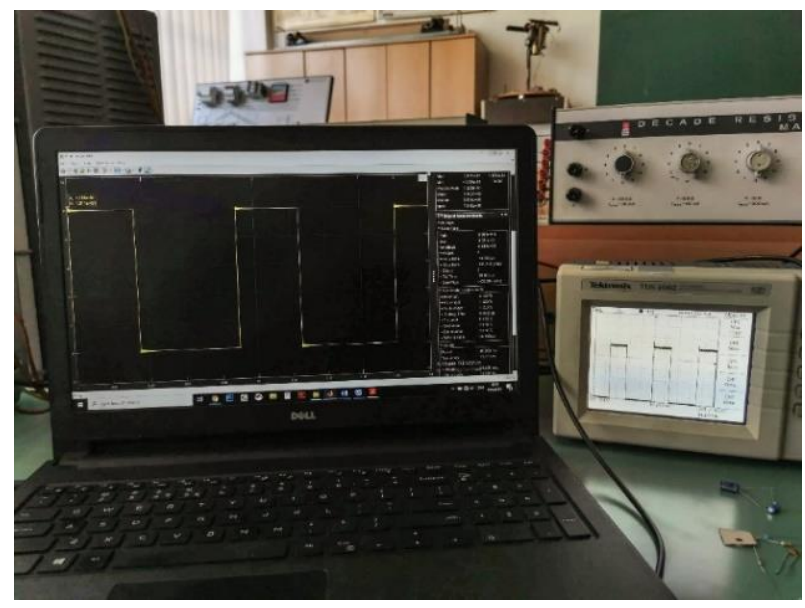

Fig. 6. Comparison between the simulated and the realistic signal

The experimental results produce nearly perfect match for a human eye. However, there were differences considering the quantification of the pulse parameters summarized in Table 2. It must be stated that in the proposed application (pulse counters, energy managements systems, etc.) these differences are not significant. But although the waveform looks roughly the same, the parameters discussed in Chapter 3 that were measured with the oscilloscope and the MATLAB simulation had significant differences. This proves the complexity of estimating the measurement uncertainty of these parameters and how many factors influence such research. These differences are due to several factors.

It was realized that the following factors have a direct impact and have influence on the measurements, but were not quantified: ambient temperature, humidity, power supply stability, cable joints, system grounding, instruments uncertainty etc.

- The simulation uses the nominal values for the $\mathrm{R}, \mathrm{L}$, and $\mathrm{C}$ components, but in the actual measurement have tolerances from the nominal values.

- The pulse generator internal impedance affect the measurements.

- Signal path effect, especially compensation probe TT-LF 312-2-6 with parasitic capacitance and time delay.

- The oscilloscope internal impedance.

- Difference in MATLAB data extraction and Tektronix FDS1002 oscilloscope software.

- Physical limitations of the function generator when generating an identical signal (e.g. transient duration or amplitude), etc.

When considering the above mentioned factors, the analysis circuit looks far more like the one given in Figure 7 rather than the one that was previously defined in Figure 4. This experiment and simulation were done to contribute to a better understanding and analysis of the factors affecting the measurement and to minimize their impact on the measurements through which the measurement uncertainty would be expressed in future research. The compared values are given in Table 2 .

Table 2

Comparison of the results

\begin{tabular}{lccc}
\hline \hline & Amplitude & Transition duration & Overshoot \\
\hline $\begin{array}{l}\text { Experimental } \\
\text { measurements }\end{array}$ & $5.03 \mathrm{~V}$ & $102,01 \mu \mathrm{s}$ & $3.976 \%$ \\
$\begin{array}{l}\text { MATLAB } \\
\text { simulation }\end{array}$ & $4.95 \mathrm{~V}$ & $76.79 \mu \mathrm{s}$ & $1.539 \%$ \\
\hline \hline
\end{tabular}




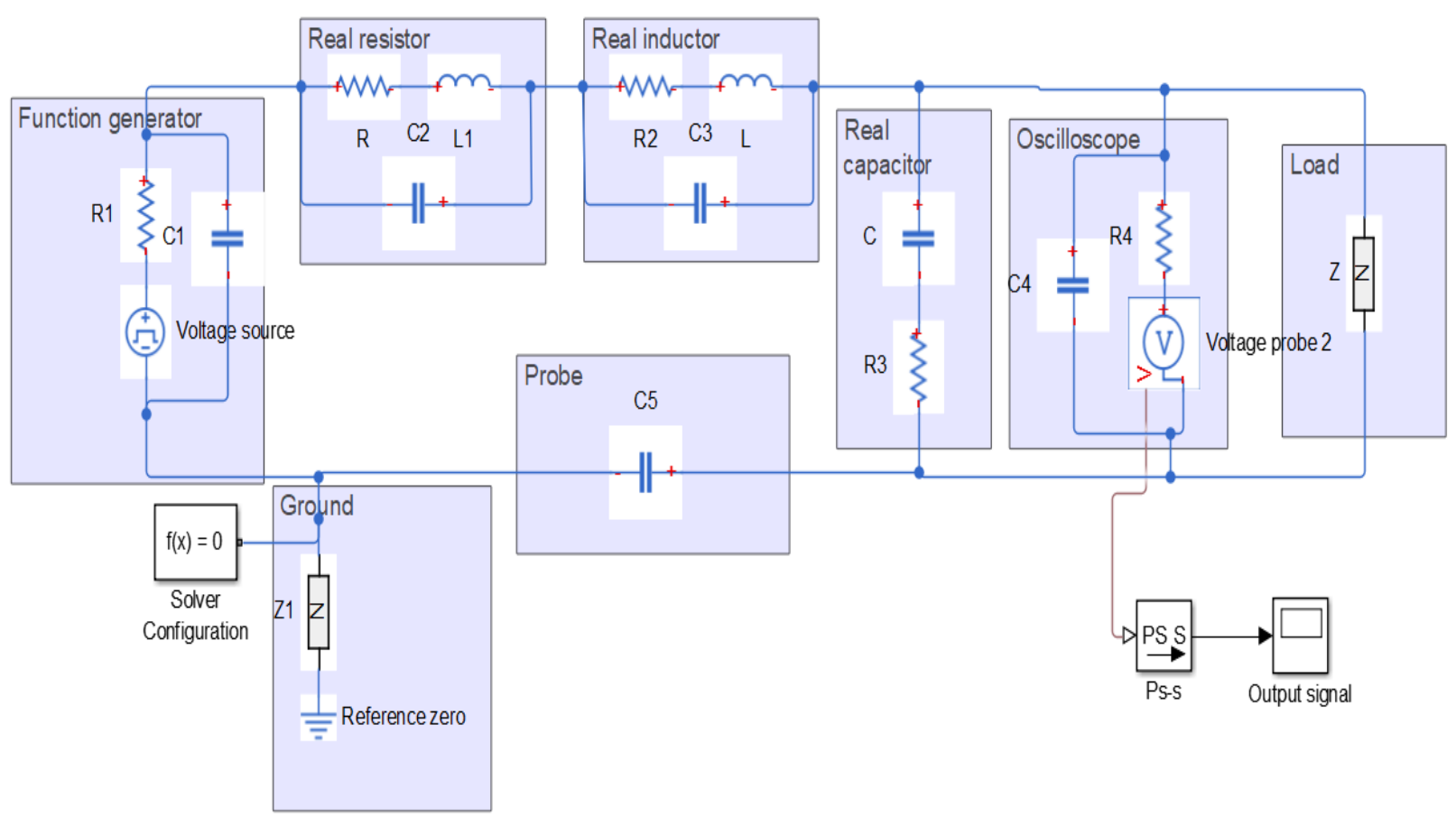

Fig. 7. Equivalent circuit model for the experimental measurements

\section{CONSLUSION}

In order to quantify the parameters of any pulse signal, good knowledge of pulse metrology and the factors affecting the measurement process are required (most importantly the instrumentation and artifacts used). It is possible to obtain this data through software simulations, but many components need to be considered in order to obtain satisfactory accuracy. As shown in this paper, the voltage related parameters were fairly close, unlike time-related parameters which show a significant difference.

It has been proven that there are differences between the IEEE standard 181-2011 computation methods and those used in commercial software for certain pulse parameters [14]. To maximize the accuracy of the comparison of parameter values, certain pulse parameters, such as pulse spectrum amplitude 0 , can be measured in more than one way. Because test methods may yield different results, they cannot be prescribed as a standard. Instead, measurement laboratories develop their own systems for measuring given parameters and rely on the use of transfer standards to demonstrate the equivalence of the methods. Future research can focus on creating more accurate simulations for this type of measurement and tests of equipment in order to create a procedure.

\section{REFERENCES}

[1] Paulter, N. G. and Larson, D. R.: Pulse metrology. Part 1., IEEE Instrum. Meas. Mag., Vol. 14, No. 3, pp. 39-44 (2011).

[2] International Vocabulary of Metrology - Basic and General Concepts and Associated Terms (VIM). ISO/IEC Guide 99:2007(E/F), ISO.

[3] IEEE Standard on Transitions, Pulses and Related Waveforms. IEEE Standard 181-2011.

[4] IEC 60469:2013 Transitions, Pulses and Related WaveForms, Terms, definitions and algorithms

[5] Paulter, N. G., Larson, D. R. and Blair, J. J.: The IEEE Standard on transitions, pulses and related waveforms, Std181-2003, In: IEEE Transactions on Instrumentation and Measurement, Vol. 53, No. 4, pp. 1209-1217, Aug. 2004, Doi: 10.1109/TIM.2004.831470.

[6] Arbitrary/Function Generators AFG 3021B - Datasheet.

[7] Digital Storage Oscilloscopes TDS1002 - Datasheet.

[8] Hale, P., Williams, D., Dienstfrey, D. A., Wang, C.-M. J., Jargon, J., Humphreys, D. A., Matthew, H., Heiko, F., Mark, M.: Traceability of high-speed electrical waveforms at NIST, NPL, and PTB. CPEM Digest (Conference on Precision Electromagnetic Measurements) (2012), pp.. 522-523. Doi 10.1109/CPEM.2012.6251033.

[9] Gong, P. et al.: Traceability of ultrafast electrical pulse waveforms at BIRMM, 2016 41st International Conference on Infrared, Millimeter, and Terahertz waves (IRMMW-THz), Copenhagen, 2016, pp. 1-2, Doi: 10.1109/IRMMW-THz.2016.7758554.

[10] IEC 62053-31. Electricity metering equipment - Particular requirements. Part 31: Pulse output devices for electromechanical and electronic meters (two wires only). 
[11] Steinger, N., Dirk, B.: Measuring, Visualizing , and Optimizing the Energy Consumption of Computer Clusters. 2017.

[12] John O. Attia: Electronics and Circuit Analysis using MATLAB, CRC Press LLC, 1999.

[13] Gavrovski, C.: Basic of Measurement Technics, Second edition, Faculty of Electrical Engineering and Information Technologyes, Skopje, 2011.
[14] Paulter, N. G., Larson, D. R.: Pulse metrology: Part 2: IEEE Instrum. Meas. Mag., Vol. 15, 43-47, pp. 39-44 (2011).

[15] Paulter, N. G., Larson, D. R.: Impulse spectrum amplitude uncertainty analysis. Metrologia, Vol. 43, pp. 477-485 (2006). 